\title{
Linguistique et technologie culturelle
}

Quelques remarques

\section{Claude Lefébure}

\section{(2) OpenEdition}

Journals

Édition électronique

URL : https://journals.openedition.org/tc/1046

DOI : $10.4000 /$ tc. 1046

ISSN : 1952-420X

Éditeur

Éditions de l'EHESS

\section{Édition imprimée}

Date de publication : 1 juin 1983

ISSN : 0248-6016

\section{Référence électronique}

Claude Lefébure, « Linguistique et technologie culturelle », Techniques \& Culture [En ligne], 1 | 1983, mis en ligne le 26 janvier 2006, consulté le 29 septembre 2022. URL : http://journals.openedition.org/tc/ 1046 ; DOI : https://doi.org/10.4000/tc. 1046

Ce document a été généré automatiquement le 29 septembre 2022.

Tous droits réservés 


\section{Linguistique et technologie culturelle}

Quelques remarques

Claude Lefébure 